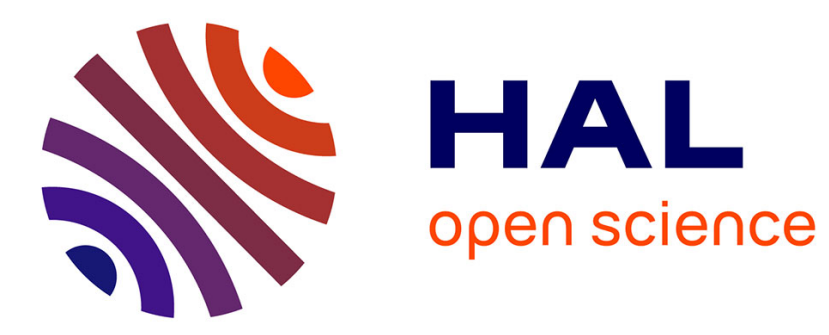

\title{
Evolution of ligands, receptors and metabolizing enzymes of thyroid signaling
}

\author{
Guillaume Holzer, Natacha Roux, Vincent Laudet
}

\section{To cite this version:}

Guillaume Holzer, Natacha Roux, Vincent Laudet. Evolution of ligands, receptors and metabolizing enzymes of thyroid signaling. Molecular and Cellular Endocrinology, 2017, 10.1016/j.mce.2017.03.021 . hal-01494487

\section{HAL Id: hal-01494487 \\ https://hal.sorbonne-universite.fr/hal-01494487}

Submitted on 23 Mar 2017

HAL is a multi-disciplinary open access archive for the deposit and dissemination of scientific research documents, whether they are published or not. The documents may come from teaching and research institutions in France or abroad, or from public or private research centers.
L'archive ouverte pluridisciplinaire HAL, est destinée au dépôt et à la diffusion de documents scientifiques de niveau recherche, publiés ou non, émanant des établissements d'enseignement et de recherche français ou étrangers, des laboratoires publics ou privés. 
Evolution of ligands, receptors and metabolizing enzymes of thyroid signaling.

Guillaume HOLZER ${ }^{1}$, Natacha ROUX ${ }^{2}$ and Vincent LAUDET ${ }^{2}$

1: Institut de Génomique Fonctionnelle de Lyon; Université de Lyon; Université Lyon 1; CNRS; Ecole Normale Supérieure de Lyon, 46 Allée d'Italie, 69364 Lyon Cedex 07, France.

2: Laboratoire de Biologie Intégrative des Organismes marins UMR 7232; CNRS et Université Pierre et Marie Curie, avenue Pierre Fabre, 66650 Banyuls-sur-Mer, France.

Abbreviated title: TH metabolism evolution

Key words: Thyroid hormone receptor, Triiodothyronine, T3, Triiodothyroacetic acid, Triac, evolution

Corresponding author: Vincent Laudet Observatoire Océanologique de Banyuls-sur-Mer, 1 avenue Pierre Fabre, 66650 Banyuls-sur-Mer, France. e-mail: vincent.laudet@obs-banyuls.fr 


\section{Abstract}

Thyroid hormones (THs) play important roles in vertebrates such as the control of the metabolism, development and seasonality. Given the pleiotropic effects of thyroid disorders (developmental delay, mood disorder, tachycardia, etc), THs signaling is highly investigated, specially using mammalian models. In addition, the critical role of TH in controlling frog metamorphosis has led to the use of Xenopus as another prominent model to study THs action. Nevertheless, animals regarded as non-model species can also improve our understanding of THs signaling. For instance, studies in amphioxus highlighted the role of Triac as a bona fide thyroid hormone receptor (TR) ligand. In this review, we discuss our current understanding of the THs signaling in the different taxa forming the metazoans (multicellular animals) group. We mainly focus on three actors of the THs signaling: the ligand, the receptor and the deiodinases, enzymes playing a critical role in THs metabolism. By doing so, we also pinpoint many key questions that remain unanswered. How can THs accelerate metamorphosis in tunicates and echinoderms while their TRs have not been yet demonstrated as functional THs receptors in these species? Do THs have a biological effect in insects and cnidarians even though they do not have any TR? What is the basic function of THs in invertebrate protostomia? These questions can appear disconnected from pharmacological issues and human applications, but the investigation of THs signaling at the metazoans scale can greatly improve our understanding of this major endocrinological pathway. 


\section{Introduction}

Thyroid hormones (THs) are involved in many biological processes in vertebrates (Holzer and Laudet, 2015), such as energy metabolism (reviewed in Mullur et al., 2014), thermoregulation (Lebon et al., 2001) but also development (Delange, 2001; Flamant et al., 2002; Göthe et al., 1999; Morte et al., 2002). In addition, THs are a critical signal triggering metamorphosis in amphibians as well as in many fishes, and are therefore important hormones that control the life cycle in vertebrates (Laudet, 2011). In humans, defects in THs signaling, either hyperthyroidism (too high THs concentration) or hypothyroidism (too low THs concentration), can lead to severe pathological conditions with a wide variety of symptoms such as tiredness, weight change, mood disorder, developmental delay, tachycardia. In addition, complete lack of THs is lethal. Thyroid cancers are the most common endocrine cancers with increasing incidence (Pacini et al., 2012). The primary treatment for such cancers is the complete or partial removal of the thyroid, leading to a massive disruption of the gland physiology (Pacini et al., 2012). Therefore, TH synthesis, its degradation and its signaling activity are the subject of many investigations.

Two molecules are collectively referred as THs: the native hormone thyroxine (3,3',5,5'-T4 or T4), which represents $80 \%$ of the hormone synthesized by the thyroid (Sapin and Schlienger, 2003), and the active hormone triiodothyronine $\left(3,3^{1}, 5-\mathrm{T} 3\right.$ or T3) that has a 10 -fold higher affinity for the receptor than T4 (Chopra, 1976). T4 is used as a precursor by three specific enzymes, the deiodinases that synthesize both active and inactive TH derivatives by catalyzing the removal of iodine atom from T4. More specifically, two reactions are distinguished. The outer ring deiodination, catalyzed by the deiodinase type II (Dio2, Kuiper et al., 2005), transforms T4 in target tissues into T3 (Figure 1). Dio2 is therefore considered as an activating deiodinase. It also turns T3 into 3,5-T2, a TH derivative long considered as inactive but for which accumulative evidences suggest a biological role (Lietzow et al., 2016; Mendoza et al., 2013). The inner ring deiodination is catalyzed by the deiodinase type III (Dio3) which is considered as an inactivating deiodinase as it turns T4 into reverse T3 (3-3'-5'-T3 or rT3) and T3 into 3-3'-T2 (Figure 1), compounds that have no biological activity (Chopra et al., 1978; Moreno et al., 2003). This process is also referred as an inner ring deiodination. The deiodinase type I (Dio1) has both outer ring and inner ring deiodination activity but with a lower activity than Dio2 and Dio3. Although it is required to regulate the normal level of $\mathrm{TH}$, its biological role is less clear (Maia et al., 2011).

THs act by binding to specific nuclear receptors: the thyroid hormone receptors (TRs), which belong to the nuclear receptor superfamily. TRs are ligand-dependent transcription factors that bind to DNA. TRs do not bind DNA alone but form a heterodimer with RXR, another nuclear receptor, and it is TR/RXR that forms the real functional unit of gene transcription control (Kojetin et al., 2015).In the classical view, TRs repress their target genes in absence of the ligand and activate them in presence of the ligand (reviewed in Gronemeyer et al., 2004). Some genes undergo a negative regulation by THs and are actively repressed by liganded TRs (Hollenberg et al., 1995; Matsunaga et al., 2015). Additionally, ligand binding influences the receptor binding on DNA (Ramadoss et al., 2014). This suggests that the biological reality of TR transcription regulation is more complex than the classical model (Flamant, 2016). There are two TRs in vertebrates, TR $\alpha$ and TRß that emerged from the whole genome duplication events at the basis of this group (Kuraku et al., 2008; Marchand et al., 2001; Smith et al., 2013). Teleost fishes underwent an additional specific whole genome duplication which results in two TR $\alpha$ genes, TR $\alpha-A$ and TR $\alpha-B$ (Escriva et al., 2004; Marchand et al., 2001). 
However, TH signaling is not a vertebrate innovation (Paris et al., 2008a) and it is established that TH-signaling was functional at the base of chordates (Paris et al., 2008a) and even possibly at the base of the bilaterians (Bertrand et al., 2004; Wu et al., 2007). Moreover, the investigation in the invertebrate chordate amphioxus (Branchiostoma sp) suggests that the 3,5,3'-triiodo-thyroacetic acid (Triac), a deaminated derivative of T3 (Figure 1), was a bona fide TRs ligand in the chordate common ancestor (Paris et al., 2008b). Thus, it is useful to describe what the studies of non-classical models bring to our understanding of TH signaling. In this review we will explore our current understanding of TH signaling in several metazoan groups starting from vertebrates toward more distant groups.

\section{Even in vertebrates, the classical ligand can hide an astonishing diversity of active compounds}

As introduced above, THs are involved in many biological processes. T3 is well acknowledged and recognized as the canonical ligand of TR in vertebrates. T4 is generally considered only as a precursor of T3 but several evidence, and in particular the recent detailed analysis of mouse strains in which the deiodinase genes have been inactivated, led to the suggestion that it may have a biological function in itself via TRs (Galton, 2017). However we will not discuss much T4 and T3 here as the latest discoveries on their biological role are covered in other chapter of this issue. We will discuss here whether other molecules could be considered as ligand and the role of the deiodinases in the modulation of TH signaling.

As previously mentioned, there are two paralogs of vertebrate TRs, TR $\alpha$ and TR 3 , which originate from the two rounds of whole genome duplication that happened at the base of all vertebrates (Kuraku et al., 2008). This duplication allows the divergence of the two copies in terms of amino acid sequence and regulatory sequence. In the mouse, TR $\alpha$ and $T R \beta$ regulate different subsets of genes, when tested in the same chromatin context, indicating that they have different intrinsic properties (Chatonnet et al., 2013). This divergence between TR $\alpha$ and TR $\beta$ led to a slightly different pharmacology between the two receptors. Indeed, there are some TR $\beta$ selective compounds such as GC-1 that have been developed for clinical purpose (Bleicher et al., 2008). TR $\alpha$ is expressed in the early development whereas TR $\beta$ is expressed later (Forrest et al., 1991), indicating differences in regulation. In amphibians as well, the timing of TR expression is different between the two paralogs. $T R \beta$ is late expressed and self-induced by the surge of T3 at metamorphosis because of a thyroid response element in the promoter of the gene (Machuca et al., 1995). This is not the case for TR $\alpha$ which is early expressed during Xenopus metamorphosis (Eliceiri and Brown, 1994; Kawahara et al., 1991; Yaoita and Brown, 1990). In teleosts, TR $\alpha-A$ and $T R \alpha-B$ are also differentially expressed as exemplified in the flounder Paralichthys olivaceus, where TR $\alpha-A$ is express earlier at a higher level than TR $\alpha-B$ and TR $\beta$ (Yamano and Miwa, 1998). This illustrates how TR duplication allows the divergence of biological roles between $T R \alpha$ and $T R \beta$.

The sea lamprey Petromyzon marinus has two TRs, TR1 and TR2, whose evolution is not clearly understood yet. Indeed, in a phylogenetic reconstruction they do not group with the TR $\alpha$ and TR $\beta$ but together within an agnathan group at the base of the gnathostomes (Manzon et al., 2014). The most singular feature of lamprey regarding TH pathway is its involvement in metamorphosis. Lamprey is the only vertebrate (to our knowledge) where a decrease of THs, instead of an increase, is observed at the onset of metamorphosis (Youson et al., 1994). Consistently with this peculiarity, THs treatments delay lamprey metamorphosis (Youson et al., 1997) while goitrogen treatments (inhibitors of TH synthesis) induce a precocious metamorphosis (Manzon et al., 2001). This is even more curious since TR1 and TR2 behave as genuine TR and transactivate target genes in presence of 
ligand (T4 or T3, Manzon et al., 2014). More curiously, the dynamic expression of lamprey TR1 during metamorphosis matches the remodeling of the tissues, suggesting that TR1 and therefore TH signaling is actively involved in metamorphosis (Manzon et al., 2014). One explanation could be that lamprey TRs behave differently in vivo than in cellulo, where their activity has been tested, because of a specific co-factor that would repress instead of activate target genes. Alternatively, it is possible that the active compound in this species is not T3 and that the decrease in T3 level corresponds to its transformation into an unknown compound that will be the endogenous TR ligand and surge during metamorphosis.

There is an increasing interest for the T3 derivative 3,5-T2 (Figure 1). Although it is classically considered as an inactive T3 derivative, 3,5-T2 actually exhibits biological activities (for review see: Orozco et al., 2014). It can induce the mRNA synthesis of several genes such as TSH (Moreno et al., 1998), Dio1 (Baur et al., 1997) or TR $\beta$ (Ball et al., 1997). More generally, in mouse, 3,5-T2 has thyromimetic activity on the hypothalamus pituitary axis and lipid metabolism (Jonas et al., 2015) as well as on the liver transcriptome (Lietzow et al., 2016). In the killifish Fundulus heteroclitus, 3,5-T2 has been shown to be a ligand for TR $\beta$ (Mendoza et al., 2013), but this idea is still debated as 3,5-T2 has a very low binding potency on TR in rat and salmon (Darling et al., 1983). Most of the studies on 3,5-T2 are now focused on its non-genomic effect, that is to say the effects that are not mediated by TRs but through cytoplasmic and membrane interactions with proteins (reviewed in Goglia, 2005).

There is another class of TH derivatives of pharmacological interest: the acid acetic analog of TH: Tetrac and Triac (Figure 1). These compounds are synthesized in peripheral tissues such as liver (Ruters et al., 1989), kidneys, (Flock et al., 1965) and brain (Rall et al., 1957) by deamination of the TH backbone. Although little is known about their metabolism, the TH aminotransferase and the L-amino acid oxydase are likely involved in their synthesis (for reviews see Engler and Burger, 1984; Wu et al., 2005). Because of its short half-life (Goslings et al., 1976; Wu et al., 2005), Triac is considered to have an overall low biological activity (Wu et al., 2005) and is not considered as a true endogenous TR ligand. Nonetheless, Triac has the same affinity for TR $\alpha$ than T3, and a two times higher affinity for TR $\beta$ than T3 (Messier et al., 2001; Schueler et al., 1990; Takeda et al., 1995), which results in a higher transcription activity (Messier et al., 2001; Schueler et al., 1990; Takeda et al., 1995). As a consequence, clinical use of Triac in hormone replacement therapy is considered to have a better outcome than T4 or T3 treatments (Guran et al., 2009; Kunitake et al., 1989). Another interesting feature of Triac is that it does not require the monocarboxylate transporter 8 (MCT8) for its cellular uptake contrary to T3 (Kersseboom et al., 2014). Therefore, Triac is a very interesting therapeutic molecule for pathologies with mutation of the MTC8 transporter. For instance, this is the case in the Allan-Herndon-Dudley syndrome where T3 uptake to the brain is impaired and T3 treatment is not effective (Kersseboom et al., 2014). This is also true for Tetrac, the acidic derivative of T4 (Figure 1), which has a very low affinity for TR but still has a biological activity in MCT8 deficient mice (Horn et al., 2013). Unfortunately, the question of the cellular uptake of Triac and Tetrac through specific transporters remains poorly investigated. Competition assay with the transporter Oatp14 shows that Triac can inhibit the uptake of T4, suggesting that Oatp14 can also transport Triac (Tohyama et al., 2004). Nevertheless, the question of the transport of Triac was not addressed directly and the affinity of the transporter for T4 is much higher than for Triac (Tohyama et al., 2004). To our knowledge, it is therefore not known how Triac and Tetrac are transported through cell membrane. Thus, although Tetrac and Triac are considered to have a low biological activity and are not viewed as canonical TR ligands, they are endogenous TH derivatives and can exert, in some 
extend, a THs signaling (reviewed in Senese et al., 2014). Another compound, the 3-lodothyronamine (T1AM), can be produced through the decarboxylation of the T4 backbone (Figure 1, for review see Scanlan, 2011). Although its synthesis and biological role remain obscure, some evidence show that they have a biological role (Braulke et al., 2008). This calls for a deeper investigation of T1AM and more generally, the decarboxylated analogs of THs.

Ligands are not the only actors capable of modulating TH signaling. As T4 is produced centrally in the thyroid gland, the deiodinases, expressed in target tissues, are key controllers of THs signaling. The importance of deiodinase is highlighted by the study of amphibian models. One striking feature of amphibian metamorphosis is the late regression of the tadpole tail. How is the tail protected from the remodeling action of thyroid hormones (which at the same time induce limb growth) during a large part of the metamorphosis? The local expression of the deiodinase provides an explanation for this phenomenon since it controls the local amount of available T3 (Becker et al., 1997; Kawahara et al., 1999). First, during early metamorphosis (stage 49, Cai and Brown, 2004) Dio2 is expressed in the limb buds, which locally turns T4 into T3, enhancing TH signaling and ultimately resulting in limbs growth and development (Brown et al., 2005). At the same time, Dio3 is highly expressed in the tail resulting in its preservation as Dio3 transforms T4 and T3 in inactive derivatives (Becker et al., 1997). As a consequence, there is no or little T3 signaling in the tail at this early period, which means limbs and tail can coexist at the same time. Later in metamorphosis (stage 62), Dio3 expression turns off in the tail, and concomitantly there is a surge of Dio2 expression. As a consequence, the local level of T3 rises and this induces the regression of the tail cells (Cai and Brown, 2004). The local expression of the deiodinases controls the local availability of THs, which explains how a systemic signaling can be delayed in a specific organ. Interestingly, this regulation at the local level of TH also happens in other species such as teleost fishes, since Dio2 and Dio3 are also differentially expressed during their metamorphosis (Campinho et al., 2012; Isorna et al., 2009). Such a local regulation is also critical in the TH effect on seasonality, which will however not be discussed here (for review see Dardente et al., 2014). The deiodinase expression seems overall conserved in vertebrates. For instance, Dio2 is expressed in the skin of amphibians and fish during their metamorphosis as well as in their brains (Becker et al., 1997; Campinho et al., 2012; Lorgen et al., 2015; Manzon and Denver, 2004). Nevertheless, some species specificities exist, as for instance Dio1 that has been lost in the amphibian Rana catesbeiana (Becker et al., 1997).

\section{In invertebrate chordates, TRIAC is an endogenous active compound....}

Because of its prominent role in frog and flatfish metamorphosis and since this process is widespread in metazoans, outside vertebrates, most of the studies on $\mathrm{TH}$ are focused on its role in post-embryonic development (Laudet, 2011).

The study of the cephalochordate Branchiostoma floridae (Figure 2) shed light on the origin of TH signaling in chordates. Indeed, its metamorphosis (the spectacular transformation of an asymmetric pelagic larva into a symmetrical benthic juvenile) is controlled by TH (Paris et al., 2008a, 2008b). The main difference though, is that the ligand of the amphioxus TR is neither T4 nor T3 which are unable to bind to the receptor, but their derivative Triac (Paris et al., 2010, 2008b). It has been shown that in amphioxus, the TR ligand binding pocket is smaller due to some specific mutations and is unable to accommodate T4 or T3. In contrast, Triac being smaller due to the lack of an amino group can enter into the pocket and regulate the conformational change of the receptor. As a consequence, the Amphioxus TR behaves as a bona fide TR: it binds DNA, forms a heterodimer with RXR, binds Triac as a ligand and induces the transactivation of target genes. Triac treatment of amphioxus larvae 
effectively leads to a precocious metamorphosis, and treatment with a TR antagonist such as NH3 delays it. TR expression peaks at metamorphosis and there is a thyroid response element in the promoter of the TR, as for TR $\beta$ in vertebrates (Paris et al., 2008b). Moreover, one of the 5 known deiodinases in $B$. floridae has been biochemically characterized and proven to be specialized in Triac deiodination (Klootwijk et al., 2011), indicating that Triac specialized metabolism effectively exists in this species. Studies of the amphioxus Branchiostoma blecheri have shown that Triac signaling regulates $\mathrm{C} / \mathrm{EBP}$, a vertebrate $\mathrm{TH}$ target gene, suggesting again a conserved TH signaling pathway in cephalochordates (Wang et al., 2009). Together, these data build the hypothesis that the TH pathway and its biological roles appear at the basis of chordates (Paris and Laudet, 2008).

\section{... but not in all known cases since the tunicate TR appears as an orphan receptor.}

In tunicates (Figure 2), another invertebrate chordate and sister group of vertebrates, TH also appears to have a role in metamorphosis. However the current situation in this group is unclear. Indeed, the role of TH is quite clear but how this role is mediated remains unknown. Some experiments suggest that $\mathrm{TH}$ treatments on larvae accelerate the (already very rapid) metamorphosis and settlement of the larvae, although this is less spectacular than in the case of amphibians or amphioxus (Patricolo et al., 1981, 2001). The presence of T4 in Ciona intestinalis has been suggested by immunodetection methods ( $D^{\prime}$ Agati and Cammarata, 2006). This is however not entirely convincing since the specificity of the antibody used is unclear, as it has been assessed only in the context of compounds known in human. Therefore, these data indicate that there probably exists a $\mathrm{TH}$-like compound, but do not formally prove that it is T4. An ortholog of vertebrate deiodinase has been identified in the tunicate Halocynthia roretzi with both T4 and rT3 as substrates (D'Agati and Cammarata, 2006; Sheperdley et al., 2004). A clear TR ortholog has been cloned, but this receptor is very divergent, in particular in the ligand binding domain (25\% sequence identity with human TRs, whereas the amphioxus LBD display 38\% (Carosa et al., 1998). Almost 20 years after its cloning, this receptor remains enigmatic as it behaves as an orphan receptor. None of the known TH derivatives are able to regulate its transcriptional activity. The original authors, as well as ourselves, have tried many different compounds but none of them are able to bind or activate the receptor (Carosa et al., 1998). Therefore, it seems clear that there is a secretion of TH-like compounds in tunicates (Hiruta et al., 2005; Ogasawara et al., 1999), but so far there is no evidence that the effects of TH on tunicates are mediated by the known TR ortholog.

\section{Echinoderms provide another mysterious case...}

Echinoderms comprise species such as sea stars, sea urchins, sea cucumbers and sand dollars (Figure 2). Our knowledge of the role of THs in the metamorphosis in echinoderms is reminiscent of the situation observed in tunicates. TH-like compounds are detected in echinoderms tissues and accelerate the complex metamorphosis of the Eiffel-tower-shaped larvae into the benthic juvenile in various sea urchins (Chino et al., 1994; Heyland et al., 2006) and sand dollars species (Heyland et al., 2004; Saito et al., 1998). T4 can also accelerate sea stars development in a dose-dependent manner (Johnson and Cartwright, 1996). Interestingly, nuclear extract of the sea urchin Hemicentrotus pulcherrimus can bind T4 (Saito et al., 2012), indicating that a factor within the nucleus, and not the cytoplasm, can bind the hormone. This may therefore be considered as an indication in favor of the presence of a nuclear receptor acting as a TR. And indeed there is a TR ortholog present in echinoderm genomes (Tu et al., 2012). Nevertheless, as in tunicates, the formal demonstration of THs binding to the isolated TR is still lacking in echinoderms. We have tested all the compounds we 
could think of in the Paracentrotus lividus TR that we have isolated in our lab, without detecting any positive hit (M. Paris, G.H. and V.L. unpublished results). Therefore, as for tunicates, it is impossible to conclude that TH signaling, through TR and transcriptional activation of target genes, is involved in echinoderm metamorphosis as in cephalochordates and vertebrates. In the sea urchin, Strongylocentrotus purpuratus, it has been shown that iodine uptake in the larvae is dependent of a peroxidase activity and not the sodium/iodine symporter found in vertebrates (Miller and Heyland, 2013). This may be reminiscent of an active thyroid function and leads to the conclusion that there is a specific iodine metabolism in echinoderms (Miller and Heyland, 2013). In any case, it indicates that the vertebrate model of iodine uptake cannot be generalized in all chordates. But if and how such a metabolism is translated to a hormonal control of life-history transition, is still an open question in these species. One explanation could be an exogenous origin of iodinated compounds, supplied by algae, which are used as hormones (Chino et al., 1994; Heyland and Moroz, 2005).

\section{A loss of TH signaling in ecdysozoa}

Genomics data indicate that there is no TR in ecdysozoans, group including insects (Bertrand et al., 2004; Figure 2) or nematodes (Kostrouchova and Kostrouch, 2015). Although some authors suggest a TR ortholog in the crustacean Daphnia pulex (Wu et al., 2007), this sequence appears divergent from the other identified TRs and is therefore not a good candidate for a TR ortholog. In addition, no experimental data confirm that the encoded protein behaves as a genuine TR.

This question is of course particularly interesting in the context of the well-known metamorphosis of arthropods and in particular in insects. However, in arthropods, metamorphosis and growth are not controlled by THs but by two other hormones: the juvenile hormone that promotes growth and prevents metamorphosis (Riddford, 1944) and the steroid derivative hormone ecdysone (reviewed in Thummel, 1996). Ecdysone binds the Ecdysone receptor, a nuclear receptor that forms a heterodimer with USP, the ortholog of RXR (Yao et al., 1994). This similarity in the biological function (post-embryonic developmental control) between THs and ecdysone and their mechanisms (nuclear receptor mediated signal) allowed some authors to draw interesting comparisons between the two signaling systems (reviewed in Flatt et al., 2006). As an illustration, TH derivatives T4, T3, rT3 and 3,5-T2 (Figure 1) have been suggested to decrease the oocyte length in the insect Locusta migratoria (Davey and Gordon, 1996; Davey, 2000). However, such an observation of the effect of an exogenously provided compound is not a proof that an endogenous pathway is regulating the process. The presence of $\mathrm{TH}$ derivative $\mathrm{T} 2$ or mono iodinated thyronine in the locust has been suggested but still lacks a clear confirmation (Flatt et al., 2006). More surprisingly, T3 seems to be able to enter insect cells and T3 treatments with a deiodinase inhibitor are less effective to reduce oocyte size than T3 alone, suggesting the existence of a deiodinase-dependent activity (Davey, 2000). Nevertheless, these data are still difficult to interpret. Since there is no TR ortholog in insects, how is this signal integrated? In addition, to our knowledge, no deiodinase has been identified in insect despite the fact that the molecular signature of those enzymes is well known. Moreover, THs bind cell membrane in insects and competes with the juvenile hormone, suggesting that the two compounds may act on the same membrane receptor (Kim et al., 1999). Thus, the TH effect observed in insects might be caused by the displacement of juvenile hormone. Furthermore, as there are no TRs, the TH binding on membrane is reminiscent of the non-genomic pathway mentioned above (reviewed in Goglia, 2005). As a conclusion, TH derivatives have some marginal effects on insects but their mechanism of action remains largely elusive, casting some doubt on the 
importance of this pathway in ecdysozoa. Given the absence of TH related genes in insects (i.e. TR, deiodinase), the presence of a chordate-like TH signaling remains dubious, and we remain on the opinion that this pathway is not endogenously present in ecdysozoa and has therefore been lost in the common ancestor of this group (see below). Nevertheless, it could be interesting to reinvestigate the influence of $\mathrm{TH}$ in insects under the light of the non-genomic pathway or the influence of iodinated compounds found in insect food (i.e. plant, Eales, 1997; Heyland and Moroz, 2005).

\section{Contrasting evidence about TH signaling in lophotrochozoans}

Lophotrochozoans (Figure 2) are the sister taxa of ecdysozoa and cluster animals such as molluscs, annelids and flatworms. The situation regarding TH signaling is very different than for ecdysozoans since their genomes contain clear TR orthologs (Bertrand et al., 2004). Moreover experimental data indicate that TH signaling is possible in this group. The suggestion of a $\mathrm{TH}$ metabolism in annelids and molluscs has been proposed in the 50's with experiments showing an incorporation of the iodine isotope $\mathrm{I}^{131}$ in their foreguts (Gorbman et al., 1954). For instance, the sea hare Aplysia californica harbors a peroxidase gene that is ortholog to the vertebrate thyroid peroxydase (TPO) that is able to incorporate $\mathrm{I}^{125}$ into T4, indicating a possible endogenous synthesis of TH (Heyland et al., 2006). Another example comes from the Pacific oyster Crassostrea gigas. HPLC experiments have shown that this mollusk contains T4 and T3. In addition its genome contains a TR that can bind DNA on a thyroid response element. However no convincing evidence of activation of this TR by THs has been reported by these authors. Their data indicate a possible weak activation at very high concentration of $\mathrm{T} 4, \mathrm{~T} 3$ and Triac $(1 \mu \mathrm{M}$, Huang et al., 2015). Therefore, the biological function of this TR ortholog remains unknown although these finding suggest that TH signaling may be functional in lophotrochozoans. At last, this allows to conclude that TR signaling must have been present in the ancestor of all bilaterian animals and that therefore, when it is not present, this means that it has been secondarily lost.

\section{TH at the base of the metazoan tree}

Genomic data from the cnidarians Acropora millepora (Grasso et al., 2001) and Nematostella vectensis (Putnam et al., 2007) or the porifera Amphimedon queenslandica (Srivastava et al., 2010) display no clear TR ortholog, suggesting that the diversification of TR from ancestral nuclear receptor did occur only in bilaterians (Bertrand et al., 2004; Tarrant, 2005). Therefore, TR should be considered as a bilaterian-specific gene (Figure2). However, some studies suggested that T4 and iodinated compounds can induce the strobilation (polyp to medusa transition) of the cnidaria Aurelia aurita (Spangenberg, 1971; Spangenberg et al., 1994), despite the absence of identified TR ortholog. This raises the following questions: How is this signaling integrated? Is there a T4-specific metabolism in cnidarians? Is this effect specific or not? The finding that the RXR ortholog of A.aurita and its ligand, 9-cis retinoic acid, are clearly involved in strobilation in the very same species is therefore puzzling (Fuchs et al., 2014). If RXR was already involved in metamorphosis control at the base of metazoans, what was the role of TR, once it appears it bilaterians, on the TR/RXR heterodimer? What is the partner, if any, of RXR in cnidarian in controlling the strobilation and other similar metamorphosis-reminiscent processes? Why is RXR always implicated in metamorphosis control in chordates (with TR) in ecdysozoan (with EcR) and in cnidarian (with still an elusive partner, if any, (Holstein and Laudet, 2014)? All these questions remain open and are very interesting path to explore in the future. 


\section{lodinated molecules in algae: what link with TH signaling?}

The synthesis of TH by the thyroid gland, with the contribution of an enormous precursor, thyroglobulin, appears clearly to be vertebrate specific (Holzer et al., 2016). This observation raises the question of how TH derivatives are formed in non vertebrate species such as amphioxus or sea urchin, which are devoid of thyroid gland. In some invertebrate chordates such as amphioxus and tunicates, the existence of an evolutionary precursor of the thyroid gland called the endostyle may provide a possible solution, but in these species there is no gene reminiscent of thyroglobulin (Holzer et al., 2016). In addition, outside chordates there is no sign of endostyle or of thyroglobulin, and the way THs are formed remains a complete mystery. However, the identification of iodine bound to organic molecules in algae, particularly cyclic ones (Barre et al., 2010; Miller and Heyland, 2010) could provide an explanation, and the supply of TH by algae (that is through feeding) have been suggested in sea urchin (Heyland and Moroz, 2005). Under this hypothesis, TR should be considered as a sensor, indicating the food availability and controlling development and life-history transitions depending on food availability. This would make sense as life-history transitional steps are always demanding and energy-consuming processes (Heyland et al., 2004 Wright et al., 2011).Furthermore, the physiological function of TR and TH in most animals in which it has been explored, mammals but also fish, is connected to energy regulation and the control of large physiological equilibria (Habibi et al., 2012; Little et al., 2013).

\section{Conclusion}

In this review, we have discussed about the main actors of TH signaling: the ligands, the receptors and the main metabolizing enzymes. We started on vertebrates, for which THs action is best understood, and discussed about related taxa for which evidence is more scarce until we reached the base of the metazoan tree, and even outside in algae (Figure 2). By doing so, we have highlighted the strong bias existing in our knowledge of the pathway (and more generally all hormones): considering the vertebrate situation as the classical situation and using it as the reference to investigate the non-vertebrate situation. This may not be (and even more: this is most probably not) what happened during evolution. Indeed, the roles of TH signaling, and what we consider as a canonical endogenous ligand (i.e. T3) might actually be a vertebrate specificity (Klootwijk et al., 2011; Paris et al., 2008a).

TH signaling is a striking example of what non classical models can bring to our understanding of an endocrinological pathway. Indeed, these models are used to address different kinds of questions that shed a new light on the biological role of THs. In particular these models allow pleading for a complete unbiased chemical and biochemical characterization of the TH-like compounds present. Several key questions on that matter remain unanswered even in mammals, in particular how deaminated derivatives such as Triac and Tetrac are formed. In addition, there are some indications that TH-like compounds may be more diverse outside vertebrates than in vertebrates. For example in amphioxus there are eight iodine symporter related genes that may participate to the transport of TH-like compounds, as well as five genes related to thyroid peroxidase and five deiodinase genes (Paris et al., 2008a), therefore suggesting an exquisite degree of sophistication in the metabolism and transport of these active compounds. Nevertheless, actual biological functions of these genes have not been investigated yet. Another interesting question would be the role of alternative ligands such as 3,5-T2 and Triac even in mammals. These have been 
dismissed as minor players but, as non-genomic action 20 years ago, should perhaps no longer be neglected. Additionally, the non-genomic effects of THs remain to be investigated outside vertebrates, which could shed a new light on the evolution of THs signaling.

Another important avenue is of course the question of the peculiar mode of formation of THs from a huge precursor protein, thyroglobulin, which exhibits a very complex trafficking in a specialized organ, the thyroid gland. This is clearly a specificity of vertebrates, which has hidden how other metazoans produce THs (or extract them from their food). This should be put in a wider perspective, namely the question of iodine supply and storage, and remains to be analyzed in an unbiased manner. We anticipate that this may provide drastic paradigm changes in the way we consider TH formation in vertebrates. The question of whether thyroglobulin is always the only precursor of TH in vertebrate may appear as heterodox but may benefit from a reappraisal.

Lastly, the connection between the three main aspects of TH in vivo function, the control of metabolism, the regulation of seasonality and the control of post-embryonic stages transitions (that is metamorphosis) remains a very important question (Holzer and Laudet, 2015). The fact that food availability is central in all these aspects is important to notice, and the role of $\mathrm{TH}$ in basic aspects of nutrition biology (from appetite regulation to digestion and growth) may provide a unifying theme for the biological role of these still enigmatic hormones. Diversity is the hallmark of biology: on thyroid hormone studies as in other aspects of our science, we should take advantage of this diversity and use it as an inspiration to explore new avenues. 
Ball S.G., Sokolov J., Chin W.W., 1997. 3, 5-Diiodo-L-thyronine (T2) has selective thyromimetic effects in vivo and in vitro.

Barre, S., Potin, P., Leblanc, C., Delage, L., 2010. The halogenated metabolism of brown algae (Phaeophyta), its biological importance and its environmental significance. Mar Drugs $8,988-1010$.

Baur, A., Bauer, K., Jarry, H., Köhrle, J., 1997. 3,5-diiodo-L-thyronine stimulates type 1 5 'deiodinase activity in rat anterior pituitaries in vivo and in reaggregate cultures and GH3 cells in vitro. Endocrinology 138, 3242-8.

Becker, K.B., Stephens, K.C., Davey, J.C., Schneider, M.J., Galton, V.A., 1997. The type 2 and type 3 iodothyronine deiodinases play important roles in coordinating development in Rana catesbeiana tadpoles. Endocrinology 138, 2989-97.

Bertrand, S., Brunet, F., Escriva, H., Parmentier, G., Laudet, V., Robinson-Rechavi, M., 2004. Evolutionary Genomics of Nuclear Receptors: From Twenty-Five Ancestral Genes to Derived Endocrine Systems. Molecular Biology and Evolution 21, 1923-1937.

Bleicher, L., Aparicio, R., Nunes, F., Martinez, L., Dias, S., Figueira, A., Santos, M., Venturelli, W., Silva, R., Donate, P., Neves, F., Simeoni, L., Baxter, J., Webb, P., Skaf, M., Polikarpov, I., 2008. Structural basis of GC-1 selectivity for thyroid hormone receptor isoforms. Bmc Struct Biol 8, 8.

Braulke, L., Klingenspor, M., DeBarber, A., Tobias, S., Grandy, D., Scanlan, T., Heldmaier, G., 2008. 3-Iodothyronamine: a novel hormone controlling the balance between glucose and lipid utilisation. J Comp Physiology B 178, 167-177.

Brown, D., Cai, L., Das, B., Marsh-Armstrong, N., Schreiber, A., Juste, R., 2005. Thyroid hormone controls multiple independent programs required for limb development in Xenopus laevis metamorphosis. P Natl Acad Sci Usa 102, 12455-12458.

Cai, L., Brown, D., 2004. Expression of type II iodothyronine deiodinase marks the time that a tissue responds to thyroid hormone-induced metamorphosis in Xenopus laevis. Developmental Biology 266, 87-95.

Campinho, M., Galay-Burgos, M., Silva, N., Costa, R., Alves, R., Sweeney, G., Power, D., 2012. Molecular and cellular changes in skin and muscle during metamorphosis of Atlantic halibut (Hippoglossus hippoglossus) are accompanied by changes in deiodinases expression. Cell Tissue Res 350, 333-346.

Carosa, E., Fanelli, A., Ulisse, S., Lauro, R., Rall, J., Jannini, E., 1998. Ciona intestinalis nuclear receptor 1: a member of steroid/thyroid hormone receptor family. P Natl Acad Sci Usa 95, 11152-7.

Chatonnet, F., Guyot, R., Benoît, G., Flamant, F., 2013. Genome-wide analysis of thyroid hormone receptors shared and specific functions in neural cells. Proc Natl Acad Sci 110, E766-E775.

Chino, Y., Saito, M., Yamasu, K., Suyemitsu, T., Ishihara, K., 1994. Formation of the adult rudiment of sea urchins is influenced by thyroid hormones. Developmental biology 161, 1-11. 
Chopra, I., Carlson, H., Solomon, D., 1978. Comparison of Inhibitory Effects of 3,5,3'Triiodothyronine (T3), Thyroxine (T4), 3,3,',5-Triiodothyronine (rT3), and 3,3'Diiodothyronine (T2) on Thyrotropin-Releasing Hormone-Induced Release of Thyrotropin in the Rat in vitro. Endocrinology 103, 393-402.

Chopra, I.J., 1976. Nature, source, and relative significance of circulating thyroid hormones. Lippincott Raven Philadelphia.

Dardente, H., Hazlerigg, D., Ebling, F., 2014. Thyroid Hormone and Seasonal Rhythmicity. Front Endocrinol 5, 19.

Darling, D.S., Dickhoff, W.W., Gorbman, A., 1983. Comparison of thyroid hormone binding to heptic nuclei of the rat and a teleost (Oncorhynchus kisutch). Endocrinology 111, 1936-43.

Davey, 2000. Do thyroid hormones function in insects? Insect biochemistry and molecular biology $30,877-84$

Davey, K.G., Gordon, D.R.B., 1996. Fenoxycarb and thyroid hormones have JH口like effects on the follicle cells of Locusta migratoria in vitro. Archives of Insect Biochemistry and Physiology 32, 613-622.

Delange, F., 2001. Iodine deficiency as a cause of brain damage. Postgraduate medical journal 77, 217-20.

D'Agati, P., Cammarata, M., 2006. Comparative analysis of thyroxine distribution in ascidian larvae. Cell Tissue Res 323, 529-535.

Eales, J.G., 1997. Iodine metabolism and thyroid-related functions in organisms lacking thyroid follicles: are thyroid hormones also vitamins? Proceedings of the Society for Experimental Biology and Medicine. Society for Experimental Biology and Medicine (New York, N.Y.) 214, 302-17.

Eliceiri, BP, Brown, DD, 1994. Quantitation of endogenous thyroid hormone receptors alpha and beta during embryogenesis and metamorphosis in Xenopus laevis. Journal of Biological Chemistry 269, 24459-65.

Engler, D., Burger, A.G., 1984. The deiodination of the iodothyronines and of their derivatives in man. Endocrine reviews 5, 151-84.

Escriva, H., Bertrand, S., Laudet, V., 2004. The evolution of the nuclear receptor superfamily. Essays in biochemistry 40, 11-26.

Flamant, F., 2016. Futures Challenges in Thyroid Hormone Signaling Research. Front Endocrinol 7,58.

Flamant, F., Poguet, A.-L.L., Plateroti, M., Chassande, O., Gauthier, K., Streichenberger, N., Mansouri, A., Samarut, J., 2002. Congenital hypothyroid Pax8(-/-) mutant mice can be rescued by inactivating the TRalpha gene. Molecular endocrinology (Baltimore, Md.) 16, 24 32.

Flatt, T., Moroz, L., Tatar, M., Heyland, A., 2006. Comparing thyroid and insect hormone signaling. Integrative and Comparative Biology 46, 777-794. 
Flock, E.V., Bollman, J.L., Owen, C.A., Zollman, P.E., 1965. Conjugation of thyroid hormones and analogs by the Gunn rat. Endocrinology 77, 303-14.

Forrest, D., Hallböök, F., Persson, H., Vennström, B., 1991. Distinct functions for thyroid hormone receptors alpha and beta in brain development indicated by differential expression of receptor genes. The EMBO journal 10, 269-75.

Fuchs, B., Wang, W., Graspeuntner, S., Li, Y., Insua, S., Herbst, E.-M., Dirksen, P., Böhm, A.-M., Hemmrich, G., Sommer, F., Domazet-Lošo, T., Klostermeier, U., Anton-Erxleben, F., Rosenstiel, P., Bosch, T., Khalturin, K., 2014. Regulation of Polyp-to-Jellyfish Transition in Aurelia aurita. Current Biology 24, 263-273.

Galton, V.A., 2017. The Ups and Downs of the Thyroxine Pro-hormone Hypothesis. Molecular and Cellular Endocrinology, in press.

Goglia, 2005. Biological effects of 3, 5-diiodothyronine (T2).

Gorbman, A., Clements, M., O'Brien, R., 1954. Utilization of radioiodine by invertebrates, with special study of several annelida and mollusca. Journal of Experimental Zoology 127, 75-92.

Goslings, B., Schwartz, H., Dillman, W., Surks, M., Oppenheimer, J., 1976. Comparison of the Metabolism and Distribution of L-Triiodothyronine and Triiodothyroaeetic Acid in the Rat: A Possible Explanation of Differential Hormonal Potency. Endocrinology 98, 666-675.

Grasso, L., Hayward, D., Trueman, J., Hardie, K., Janssens, P., Ball, E., 2001. The evolution of nuclear receptors: evidence from the coral Acropora. Mol Phylogenet Evol 21, 93-102.

Gronemeyer, H., Gustafsson, J.-A.A., Laudet, V., 2004. Principles for modulation of the nuclear receptor superfamily. Nat Rev Drug Discov 3, 950-64.

Guran, T., Turan, S., Bircan, R., Bereket, A., 2009. 9 years follow-up of a patient with pituitary form of resistance to thyroid hormones (PRTH): comparison of two treatment periods of D-thyroxine and triiodothyroacetic acid (TRIAC). Journal of pediatric endocrinology \& metabolism: JPEM 22, 971-8.

Göthe, S., Wang, Z., Ng, L., Nilsson, J., Campos-Barros, A., Ohlsson, C., Vennström, B., Forrest, D., 1999. Mice devoid of all known thyroid hormone receptors are viable but exhibit disorders of the pituitary-thyroid axis, growth and bone maturation. Genes and Development $13,1329-1341$.

Habibi, H.R., Nelson, E.R., Allan, E.R.O., 2012. New insights into thyroid hormone function and modulation of reproduction in goldfish. Gen Comp Endocr 175, 19-26.

Heyland, A., Moroz, L., 2005. Cross-kingdom hormonal signaling: an insight from thyroid hormone functions in marine larvae. J Exp Biology 208, 4355-61.

Heyland, A., Price, D., Bodnarova-Buganova, M., Moroz, L., 2006. Thyroid hormone metabolism and peroxidase function in two non-chordate animals. J Exp Zoology Part B Mol Dev Evol 306, 551-66.

Heyland, A., Reitzel, A.M., Hodin, J., 2004. Thyroid hormones determine developmental mode in sand dollars (Echinodermata: Echinoidea). Evolution \& development 6, 382-92. 
Hiruta, J., Mazet, F., Yasui, K., Zhang, P., Ogasawara, M., 2005. Comparative expression analysis of transcription factor genes in the endostyle of invertebrate chordates. Dev Dynam 233, 1031-1037.

Hollenberg, A., Monden, T., Flynn, T., Boers, M., Cohen, O., Wondisford, F., 1995. The human thyrotropin-releasing hormone gene is regulated by thyroid hormone through two distinct classes of negative thyroid hormone response elements. Mol Endocrinol Baltim Md 9, 540-50.

Holstein, T.W., Laudet, V., 2014. Life-history evolution: at the origins of metamorphosis. Curr. Biol. 24, R159-61.

Holzer, G., Laudet, V., 2015. Thyroid hormones: a triple-edged sword for life history transitions. Curr. Biol. 25, R344-7.

Holzer, G., Morishita, Y., Fini, J.-B., Lorin, T., Gillet, B., Hughes, S., Tohmé, M., Deléage, G., Demeneix, B., Arvan, P., Laudet, V., 2016. Thyroglobulin Represents a Novel Molecular Architecture of Vertebrates. J Biol Chem 291, 16553-16566.

Horn, S., Kersseboom, S., Mayerl, S., Müller, J., Groba, C., Trajkovic-Arsic, M., Ackermann, T., Visser, T.J., Heuer, H., 2013. Tetrac Can Replace Thyroid Hormone During Brain Development in Mouse Mutants Deficient in the Thyroid Hormone Transporter Mct8. Endocrinology 154, 968-979.

Huang, W., Xu, F., Qu, T., Zhang, R., Li, L., Que, H., Zhang, G., 2015. Identification of Thyroid Hormones and Functional Characterization of Thyroid Hormone Receptor in the Pacific Oyster Crassostrea gigas Provide Insight into Evolution of the Thyroid Hormone System. PLOS ONE 10, e0144991.

Isorna, E., Obregon, M., Calvo, R., Vázquez, R., Pendón, C., Falcón, J., Muñoz $\square$ Cueto, J., 2009. Iodothyronine deiodinases and thyroid hormone receptors regulation during flatfish (Solea senegalensis) metamorphosis. J Exp Zoology Part B Mol Dev Evol 312B, 231-246.

Johnson, L.G., Cartwright, C.M., 1996. Thyroxine-Accelerated Larval Development in the Crown-of-Thorns Starfish, Acanthaster planci. Biological Bulletin 190, $299-301$.

Jonas, W., Lietzow, J., Wohlgemuth, F., Hoefig, C., Wiedmer, P., Schweizer, U., Köhrle, J., Schürmann, A., 2015. 3,5-Diiodo-L-Thyronine (3,5-T2) Exerts Thyromimetic Effects on Hypothalamus-Pituitary-Thyroid Axis, Body Composition, and Energy Metabolism in Male Diet-Induced Obese Mice. Endocrinology 156, 389-399.

Kawahara, A., Baker, B., Tata, J., 1991. Developmental and regional expression of thyroid hormone receptor genes during Xenopus metamorphosis. Development (Cambridge, England) $112,933-43$.

Kawahara, A., Gohda, Y., Hikosaka, A., 1999. Role of type III iodothyronine 5ロdeiodinase gene expression in temporal regulation of Xenopus metamorphosis. Development, Growth \& Differentiation 41, 365-373.

Kersseboom, S., Horn, S., Visser, W.E., Chen, J., Friesema, E.C., Vaurs-Barrière, C., Peeters, R.P., Heuer, H., Visser, T.J., 2014. In Vitro and Mouse Studies Supporting Therapeutic Utility of Triiodothyroacetic Acid in MCT8 Deficiency. Molecular Endocrinology 28, 19611970. 
Kim, Y., Davari, E., Sevala, V., Davey, K., 1999. Functional binding of a vertebrate hormone, L-3,5,3'-triiodothyronine (T3), on insect follicle cell membranes. Insect biochemistry and molecular biology 29, 943-50.

Klootwijk, W., Friesema, E., Visser, T., 2011. A Nonselenoprotein from Amphioxus Deiodinates Triac But Not T3: Is Triac the Primordial Bioactive Thyroid Hormone? Endocrinology 152, 3259-3267.

Kojetin, D., Matta-Camacho, E., Hughes, T., Srinivasan, S., Nwachukwu, J., Cavett, V., Nowak, J., Chalmers, M., Marciano, D., Kamenecka, T., Shulman, A., Rance, M., Griffin, P., Bruning, J., Nettles, K., 2015. Structural mechanism for signal transduction in RXR nuclear receptor heterodimers. Nat Commun 6, 8013.

Kostrouchova, M., Kostrouch, Z., 2015. Nuclear receptors in nematode development: Natural experiments made by a phylum. Biochim. Biophys. Acta 1849, 224-37.

Kuiper, G., Kester, M., Peeters, R., Visser, T., 2005. Biochemical mechanisms of thyroid hormone deiodination. Thyroid 15, 787-98.

Kunitake, J., Hartman, N., Henson, L., Lieberman, J., Williams, D., Wong, M., Hershman, J., 1989. 3,5,3'-Triiodothyroacetic Acid Therapy for Thyroid Hormone Resistance. The Journal of Clinical Endocrinology \& Metabolism 69, 461-466.

Kuraku, S., Meyer, A., Kuratani, S., 2008. Timing of genome duplications relative to the origin of the vertebrates: did cyclostomes diverge before or after? Mol Biol Evol 26, 47-59.

Laudet, V., 2011. The origins and evolution of vertebrate metamorphosis. Curr Biology $\mathrm{Cb}$ 21, R726-37.

Lebon, V., Dufour, S., Petersen, K.F., Ren, J., Jucker, B.M., Slezak, L.A., Cline, G.W., 2001. Effect of triiodothyronine on mitochondrial energy coupling in human skeletal muscle. The Journal of Clinical investigation 108, 733-737.

Lietzow, J., Golchert, J., Homuth, G., Völker, U., Jonas, W., Köhrle, J., 2016. 3,5-T2 alters murine genes relevant for xenobiotic, steroid, and thyroid hormone metabolism. J Mol Endocrinol 56, 311-323.

Little, A., Kunisue, T., Kannan, K., Seebacher, F., 2013. Thyroid hormone actions are temperature-specific and regulate thermal acclimation in zebrafish (Danio rerio). Bmc Biol $11,1-15$.

Lorgen, M., Casadei, E., Król, E., Douglas, A., Birnie, M.J., Ebbesson, L.O.E., Nilsen, T.O., Jordan, W.C., Jørgensen, E., Dardente, H., Hazlerigg, D.G., Martin, S.A.M., 2015. Functional Divergence of Type 2 Deiodinase Paralogs in the Atlantic Salmon. Curr Biol 25, 936-941.

Machuca, I., Esslemont, G., Fairclough, L., Tata, J.R., 1995. Analysis of structure and expression of the Xenopus thyroid hormone receptor-beta gene to explain its autoinduction. Molecular Endocrinology 9, 96-107.

Maia, A.L., Goemann, I.M., Meyer, E.L., Wajner, S.M., 2011. Deiodinases: the balance of thyroid hormone: type 1 iodothyronine deiodinase in human physiology and disease. J. Endocrinol. 209, 283-97. 
Manzon, Denver, 2004. Regulation of pituitary thyrotropin gene expression during Xenopus metamorphosis: negative feedback is functional throughout metamorphosis. Journal of Endocrinology 182, 273-285.

Manzon, L., Youson, J., Holzer, G., Staiano, L., Laudet, V., Manzon, R., 2014. Thyroid hormone and retinoid $\mathrm{X}$ receptor function and expression during sea lamprey (Petromyzon marinus) metamorphosis. Gen Comp Endocr 204, 211-222.

Manzon, R., Holmes, J., Youson, J., 2001. Variable effects of goitrogens in inducing precocious metamorphosis in sea lampreys (Petromyzon marinus). J Exp Zool 289, 290-303.

Marchand, O., Safi, R., Escriva, H., Rompaey, E., Prunet, P., Laudet, V., 2001. Molecular cloning and characterization of thyroid hormone receptors in teleost fish. J Mol Endocrinol $26,51-65$.

Matsunaga, H., Sasaki, S., Suzuki, S., Matsushita, A., Nakamura, H., Nakamura, H.M., Hirahara, N., Kuroda, G., Iwaki, H., Ohba, K., Morita, H., Oki, Y., Suda, T., 2015. Essential Role of GATA2 in the Negative Regulation of Type 2 Deiodinase Gene by Liganded Thyroid Hormone Receptor $\beta 2$ in Thyrotroph. PLoS ONE 10, e0142400.

Mendoza, A., P, Hernández-Puga, G., Villalobos, P., Holzer, G., Renaud, J., Laudet, V., Orozco, A., 2013. 3,5-T2 Is an Alternative Ligand for the Thyroid Hormone Receptor $\beta 1$. Endocrinology 154, 2948-2958.

Messier, N., Laflamme, L., Hamann, G., Langlois, M.., 2001. In vitro effect of Triac on resistance to thyroid hormone receptor mutants: potential basis for therapy. Mol Cell Endocrinol 174, 59-69.

Miller, A., Heyland, A., 2010. Endocrine interactions between plants and animals: Implications of exogenous hormone sources for the evolution of hormone signaling. Gen Comp Endocr 166, 455-461.

Miller, A., Heyland, A., 2013. Iodine accumulation in sea urchin larvae is dependent on peroxide. J Exp Biology 216, 915-926.

Moreno, J., Vijlder, J. de, Vulsma, T., Ris-Stalpers, C., 2003. Genetic basis of hypothyroidism: recent advances, gaps and strategies for future research. Trends in Endocrinology \& Metabolism 14, 318326.

Moreno, M., Lombardi, A., Lombardi, P., Goglia, F., Lanni, A., 1998. Effect of 3,5-diiodo-Lthyronine on thyroid stimulating hormone and growth hormone serum levels in hypothyroid rats. Life Sciences 62, 2369-2377.

Morte, B., Manzano, J., Scanlan, T., Vennstrom, B., Bernal, J., 2002. Deletion of the thyroid hormone receptor alpha 1 prevents the structural alterations of the cerebellum induced by hypothyroidism Proceeding of the National Academy of Science 99, 3985-3989.

Mullur, R., Liu, Y.-Y., Brent, G., 2014. Thyroid Hormone Regulation of Metabolism. Physiological Reviews 94, 355-382.

Ogasawara, M., Lauro, R. Di, Satoh, N., 1999. Ascidian homologs of mammalian thyroid peroxidase genes are expressed in the thyroid-equivalent region of the endostyle. J. Exp. Zool. $285,158-69$. 
Orozco, A., Navarrete-Ramírez, P., Olvera, A., García-G, C., 2014. 3,5-Diiodothyronine (T2) is on a role. A new hormone in search of recognition. General and Comparative Endocrinology 203, 174-180.

Pacini, F., Castagna, M., Brilli, L., Pentheroudakis, G., Group, E., 2012. Thyroid cancer: ESMO Clinical Practice Guidelines for diagnosis, treatment and follow-up. Ann Oncol 23, vii110-vii119.

Paris, M., Brunet, F., Markov, G., Schubert, M., Laudet, V., 2008a. The amphioxus genome enlightens the evolution of the thyroid hormone signaling pathway. Dev Genes Evol 218, $667-680$.

Paris, M., Escriva, H., Schubert, M., Brunet, F., Brtko, J., Ciesielski, F., Roecklin, D., VivatHannah, V., Jamin, E., Cravedi, J.-P., Scanlan, T., Renaud, J.-P., Holland, N., Laudet, V., 2008b. Amphioxus postembryonic development reveals the homology of chordate metamorphosis. Current biology : CB 18, 825-30.

Paris, M., Hillenweck, A., Bertrand, S., Delous, G., Escriva, H., Zalko, D., Cravedi, J.-P., Laudet, V., 2010. Active Metabolism of Thyroid Hormone During Metamorphosis of Amphioxus. Integr Comp Biol 50, 63-74.

Paris, M., Laudet, V., 2008. The history of a developmental stage: Metamorphosis in chordates. Genesis 46, 657-672.

Patricolo, E., Cammarata, M., D’Agati, P., 2001. Presence of thyroid hormones in ascidian larvae and their involvement in metamorphosis. The Journal of experimental zoology 290, 426-30.

Patricolo, Ortolani, Cascio, 1981. The effect of L-thyroxine on the metamorphosis of Ascidia malaca. Cell and Tissue Research 214.

Putnam, N., Srivastava, M., Hellsten, U., Dirks, B., Chapman, J., Salamov, A., Terry, A., Shapiro, H., Lindquist, E., Kapitonov, V., Jurka, J., Genikhovich, G., Grigoriev, I., Lucas, S., Steele, R., Finnerty, J., Technau, U., Martindale, M., Rokhsar, D., 2007. Sea Anemone Genome Reveals Ancestral Eumetazoan Gene Repertoire and Genomic Organization. Science 317, 86-94.

Rall, J.E., Rawson, R.W., Tata, J.R., 1957. Metabolism of L-thyroxine and L-3:5:3'triiodothyronine by brain tissue preparations. Endocrinology 60, 83-98.

Ramadoss, P., Abraham, B., Tsai, L., Zhou, Y., Costa-e-Sousa, R., Ye, F., Bilban, M., Zhao, K., Hollenberg, A., 2014. Novel Mechanism of Positive versus Negative Regulation by Thyroid Hormone Receptor $\beta 1$ (TR $\beta 1$ ) Identified by Genome-wide Profiling of Binding Sites in Mouse Liver. J Biol Chem 289, 1313-1328.

Riddford, L.M., 1944. Cellular and Molecular Actions of Juvenile Hormone 1. General Considerations and Premetamorphic Actions. Academic Press Limited.

Ruters, M., Heudsens, F., Bonthuis, F., Visser, T., 1989. Metabolism of Triiodothyroacetic Acid (TA3) in Rat Liver. II. Deiodination and Conjugation of TA3by Rat Hepatocytes and in Rats in Vivo. Endocrinology 125, 433-443. 
Saito, M., Seki, M., Amemiya, S., Yamasu, K., Suyemitsu, T., Ishihara, K., 1998. Induction of metamorphosis in the sand dollar Peronella japonica by thyroid hormones. Development, growth \& differentiation 40, 307-12.

Saito, M., Yamasu, K., Suyemitsu, T., 2012. Binding Properties of Thyroxine to Nuclear Extract from Sea Urchin Larvae. Zool Sci 31, 79-82.

Sapin, R., Schlienger, J.-L.L., 2003. Thyroxine (T4) and tri-iodothyronine (T3) determinations: techniques and value in the assessment of thyroid function. Annales de biologie clinique 61, 411-20.

Scanlan, T., 2011. Endogenous 3-Iodothyronamine (T1AM): More Than We Bargained For. J Clin Endocrinol Metabolism 96, 1674-1676.

Schueler, P., Schwartz, H., Strait, K., Mariash, C., Oppenheimer, J., 1990. Binding of 3,5,3'triiodothyronine (T3) and its analogs to the in vitro translational products of c-erbA protooncogenes: differences in the affinity of the alpha- and beta-forms for the acetic acid analog and failure of the human testis and kidney alpha-2 products to bind T3. Mol Endocrinol Baltim Md 4, 227-34.

Senese, R., Cioffi, F., Lange, P., Goglia, F., Lanni, A., 2014. Thyroid: biological actions of "nonclassical" thyroid hormones. Journal of Endocrinology 221, R1-R12.

Sheperdley, C.A., Klootwijk, W., Makabe, K.W., Visser, T.J., Kuiper, G.G., 2004. An Ascidian Homolog of Vertebrate Iodothyronine Deiodinases. Endocrinology 145, 1255-1268.

Smith, J., Kuraku, S., Holt, C., Sauka-Spengler, T., Jiang, N., Campbell, M., Yandell, M., Manousaki, T., Meyer, A., Bloom, O., Morgan, J., Buxbaum, J., Sachidanandam, R., Sims, C., Garruss, A., Cook, M., Krumlauf, R., Wiedemann, L., Sower, S., Decatur, W., Hall, J., Amemiya, C., Saha, N., Buckley, K., Rast, J., Das, S., Hirano, M., McCurley, N., Guo, P., Rohner, N., Tabin, C., Piccinelli, P., Elgar, G., Ruffier, M., Aken, B., Searle, S., Muffato, M., Pignatelli, M., Herrero, J., Jones, M., Brown, C., Chung-Davidson, Y.-W., Nanlohy, K., Libants, S., Yeh, C.-Y., McCauley, D., Langeland, J., Pancer, Z., Fritzsch, B., Jong, P., Zhu, B., Fulton, L., Theising, B., Flicek, P., Bronner, M., Warren, W., Clifton, S., Wilson, R., Li, W., 2013. Sequencing of the sea lamprey (Petromyzon marinus) genome provides insights into vertebrate evolution. Nat Genet 45, 415-21, 421e1-2.

Spangenberg, D.B., 1971. Thyroxine induced metamorphosis in Aurelia. The Journal of experimental zoology 178, 183-94.

Spangenberg, D.B., Jernigan, T., McCombs, R., 1994. Development studies of Aurelia (jellyfish) ephyrae which developed during the SLS-1 mission. Advanced Space Research 14, 239-247.

Srivastava, M., Simakov, O., Chapman, J., Fahey, B., Gauthier, M., Mitros, T., Richards, G., Conaco, C., Dacre, M., Hellsten, U., Larroux, C., Putnam, N., Stanke, M., Adamska, M., Darling, A., Degnan, S., Oakley, T., Plachetzki, D., Zhai, Y., Adamski, M., Calcino, A., Cummins, S., Goodstein, D., Harris, C., Jackson, D., Leys, S., Shu, S., Woodcroft, B., Vervoort, M., Kosik, K., Manning, G., Degnan, B., Rokhsar, D., 2010. The Amphimedon queenslandica genome and the evolution of animal complexity. Nature 466, 720-726. 
Takeda, T., Suzuki, S., Liu, R.-T., DeGroot, L.J., 1995. Triiodothyroacetic Acid Has Unique Potential for Therapy of Resistance to Thyroid Hormone. Journal of Clinical Endocrinology and Metabolism 80, 2033-2040.

Tarrant, A.M., 2005. Endocrine-like Signaling in Cnidarians: Current Understanding and Implications for Ecophysiology. Integr. Comp. Biol. 45, 201-14.

Thummel, C.S., 1996. Flies on steroids--Drosophila metamorphosis and the mechanisms of steroid hormone action. Trends in genetics : TIG 12, 306-10.

Tohyama, K., Kusuhara, H., Sugiyama, Y., 2004. Involvement of Multispecific Organic Anion Transporter, Oatp14 (Slc21a14), in the Transport of Thyroxine across the Blood-Brain Barrier. Endocrinology 145, 4384-4391.

Tu, Q., Cameron, R., Worley, K., Gibbs, R., Davidson, E., 2012. Gene structure in the sea urchin Strongylocentrotus purpuratus based on transcriptome analysis. Genome Res 22, 2079-2087.

Wang, S., Zhang, S., Zhao, B., Lun, L., 2009. Up-regulation of C/EBP by thyroid hormones: A case demonstrating the vertebrate-like thyroid hormone signaling pathway in amphioxus. Mol Cell Endocrinol 313, 57-63.

Wright, M., Richardson, S., Bigos, J., 2011. The fat body of bullfrog (Lithobates catesbeianus) tadpoles during metamorphosis: Changes in mass, histology, and melatonin content and effect of food deprivation. Comp Biochem Physiology Part Mol Integr Physiology 160, 498-503.

Wu, S.-Y.Y., Green, W.L., Huang, W.-S.S., Hays, M.T., Chopra, I.J., 2005. Alternate pathways of thyroid hormone metabolism. Thyroid 15, 943-58.

Wu, W., Niles, E.G., LoVerde, P.T., 2007. Thyroid hormone receptor orthologues from invertebrate species with emphasis on Schistosoma mansoni. BMC Evol. Biol. 7, 150.

Yamano, K., Miwa, S., 1998. Differential Gene Expression of Thyroid Hormone Receptor $\alpha$ and $\beta$ in Fish Development. Gen Comp Endocr 109, 75-85.

Yao, T.P., Forman, B.M., Jiang, Z., Cherbas, L., Chen, J.D., McKeown, M., Cherbas, P., Evans, R.M., 1994. Functional ecdysone receptor is the product of EcR and Ultraspiracle genes. Nature 366, 476-9.

Yaoita, Y., Brown, D.D., 1990. A correlation of thyroid hormone receptor gene expression with amphibian metamorphosis. Genes \& development 4, 1917-24.

Youson, J., Manzon, R., Peck, B., Holmes, J., 1997. Effects of exogenous thyroxine (T4) and triiodothyronine (T3) on spontaneous metamorphosis and serum T4 and T3 levels in immediately premetamorphic sea lampreys, Petromyzon marinus. J Exp Zool 279, 145-155.

Youson, J.H., Plisetskaya, E.M., Leatherland, J.F., 1994. Concentrations of insulin and thyroid hormones in the serum of landlocked sea lampreys (Petromyzon marinus) of three larval year classes, in larvae exposed to two temperature regimes, and in individuals during and after metamorphosis. Gen. Comp. Endocrinol. 94, 294-304. 


\section{Legend}

Figure 1: The classical TH derivatives. Inner and outer rings are indicated above T4. Red arrows indicate outer ring deiodination performed by Dio2. Blue arrows indicate inner ring deiodination performed by Dio3. Grey arrows indicate deiodination performed by Dio1. Green arrows indicate deaminations. The orange arrow indicates a decarboxylation. The interrogation mark under the T1AM indicates that although possible from $\mathrm{TH}$, the synthesis of this compound remains unknown.

Figure 2: Schematic metazoan phylogeny. The phylogenetic relationships between the main taxonomic groups discussed in this review are represented. Each group is indicated by a bracket. The vertebrate specific TR duplication is indicated. 


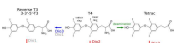

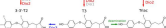

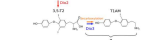

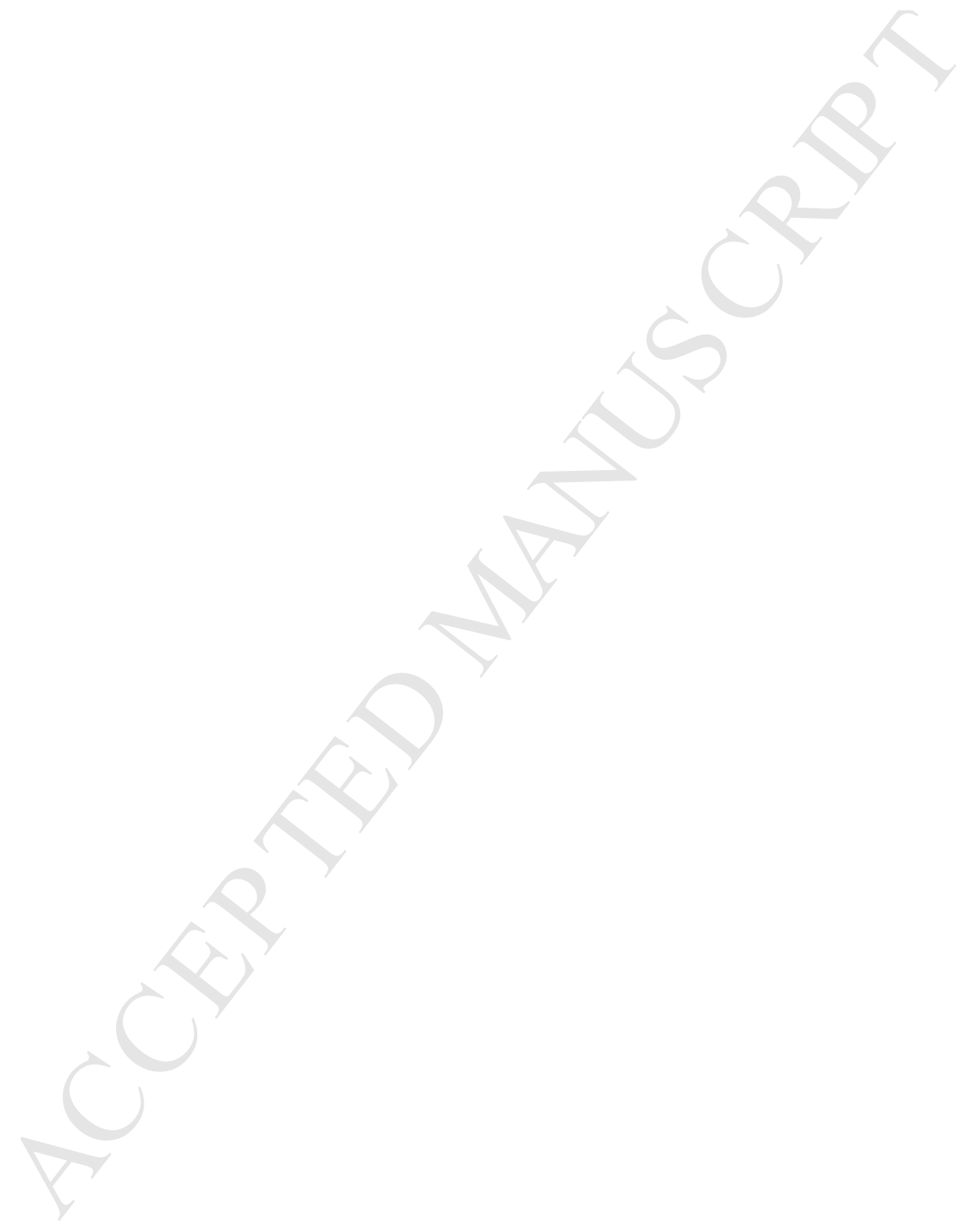




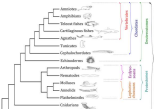

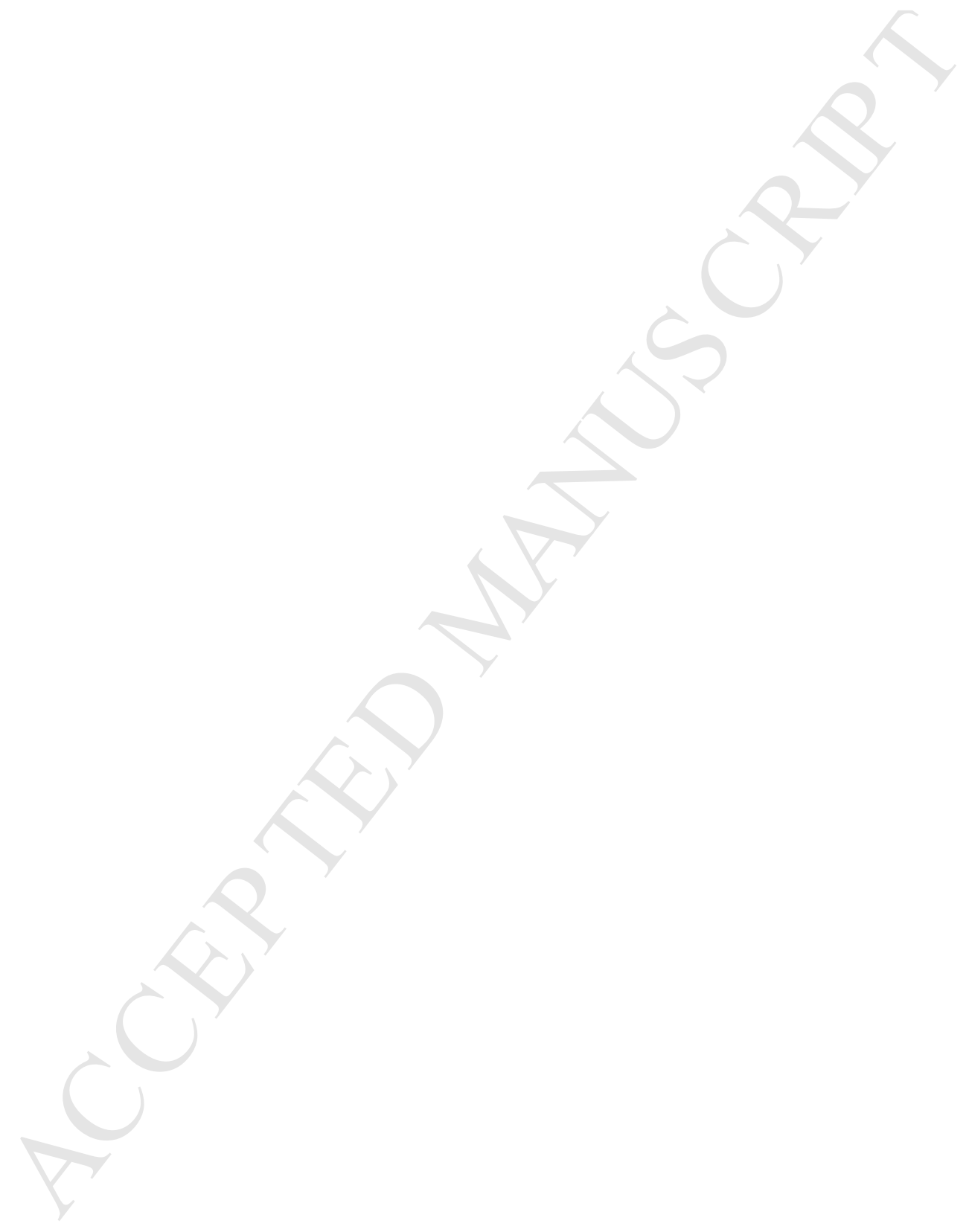


Holzer et al., Highlights

The biological role of non-canonical ligands remains to be explored in vertebrates.

Comparative endocrinology shows that T4 and T3 might not be the original TR ligands.

The role of non-canonical ligands remains to be understood outside vertebrates. 